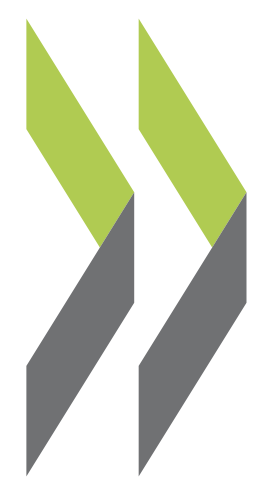

OECD Economics Department Working Papers No. 466

$$
\text { Is there a Case }
$$

for Sophisticated Balanced-

Antonio Fatás

$$
\text { Budget Rules? }
$$


Organisation de Coopération et de Développement Economiques

ECONOMICS DEPARTMENT

IS THERE A CASE FOR SOPHISTICATED BALANCED-BUDGET RULES?

ECONOMICS DEPARTMENT WORKING PAPERS No. 466

by

Antonio Fatás

All Economics Department Working Papers are available through OECD's Internet Web site at www.oecd.org/eco 


\section{TABLE OF CONTENTS}

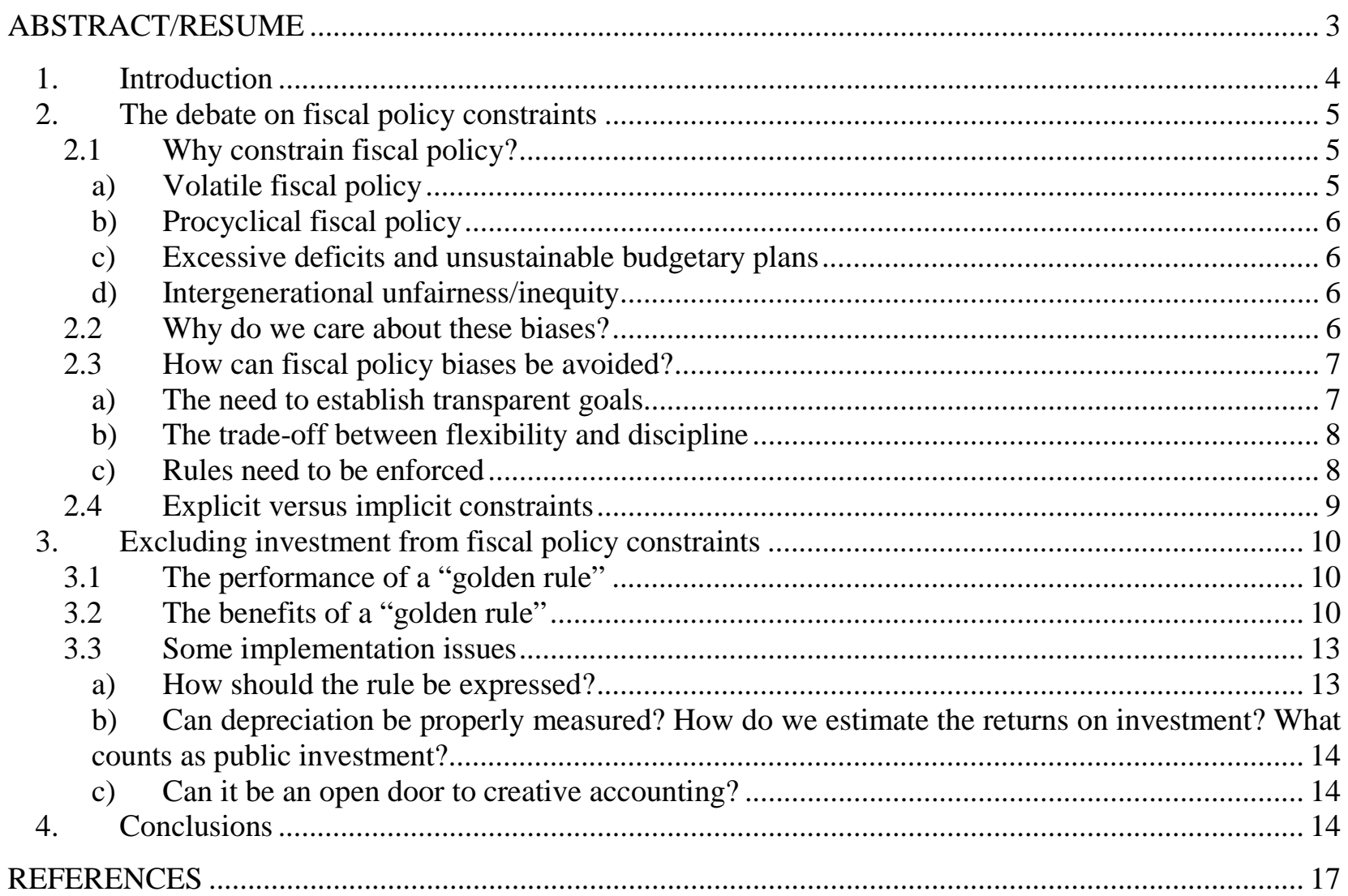




\section{ABSTRACT/RESUME}

\section{Is there a case for sophisticated balanced-budget rules?}

This paper reviews the arguments in favor of excluding investment from fiscal policy constraints (the adoption of a "golden rule"). The paper starts by reviewing the goals and motivations of fiscal policy rules. From this analysis, it is clear that answering the question of whether investment should be excluded from those constraints can only be done once the goals and logic of those constraints are made clear. The strongest arguments in favor of a "golden rule" are those of transparency and intergenerational fairness. Other arguments, such as the possibility that public investment pays for itself, do not receive strong empirical support. The paper concludes that for a policy rule to be sustainable and have enough political and public support, it is necessary to have a proper, transparent and, therefore, different accounting treatment for investment. Whether this implies that investment should be completely excluded from fiscal policy constraints is left as an open question.

JEL classification: E32, H30

Keywords: fiscal policy, fiscal rules, business cycles

$* * * * *$

\section{Les arguments en faveur de règles sophistiquées d'équilibre budgétaires sont-ils légitimes?}

Cet article analyse les arguments en faveur de l'exclusion de l'investissement des contraintes de politique budgétaire (adoption d'une « règle d'or»). Il commence par passer en revue les buts et les motivations des règles de politique budgétaire. Il en ressort qu'avant de pouvoir répondre à la question de savoir si oui ou non l'investissement doit être exclu de ces contraintes, il est essentiel que les buts et la logique qui les sous-tendent soient clairement énoncés. Les arguments les plus solides en faveur d'une "règle d'or" sont ceux de la transparence et de l'équité transgénérationnelle. D'autres arguments, tels que le fait que l'investissement s'autofinancerait, ne reçoivent pas beaucoup de validation empirique. L'auteur en conclut que pour qu'une règle budgétaire soit soutenable et reçoive suffisamment de soutien des acteurs politiques et de la population, il est nécessaire que l'investissement fasse l'objet d'un traitement comptable spécifique, transparent et par conséquent différent. La question de savoir si cela implique que l'investissement soit complètement exclu des contraintes de politique budgétaire reste une question ouverte.

JEL codes : E32, H30

Mots clés : Politique budgétaire, règles budgétaires, cycles économiques

\section{Copyright OECD, 2005}

Applications for permission to reproduce or translate all, or part of, this material should be made to: Head of Publications Service, OECD, 2 rue André-Pascal, 75775 Paris Cédex 16, France. 


\title{
IS THERE A CASE FOR SOPHISTICATED BALANCED-BUDGET RULES?
}

\author{
Antonio Fatás ${ }^{1}$
}

\section{Introduction}

1. The recent behaviour of governments in many countries around the world to control budget balances has led to a renewed interest by policy makers and academics in fiscal policy constraints. In the case of the United States, a surplus that vanished into one of the largest post-war deficits has added arguments to a long-standing debate on constraining fiscal policy; a debate that in the past has been focused around the proposals for a balanced budget amendment. Among developing countries, the debate is not new either. The poor management of fiscal policy in these countries has been responsible for increased volatility on their business cycles and recurrent crises. At the same time, the discipline imposed on fiscal policy by consolidation plans has left some of these countries with an important infrastructure gap, one that is partially responsible for their bad growth performance.

2. In Europe, the debate on the role of fiscal discipline has become particularly intense on the issue of how appropriate the rules contained in the Stability and Growth Pact are. While there might be benefits to constraining fiscal policy, there is growing concern that the costs in terms of lack of flexibility or in terms of negative consequences on long-term growth are too large. While constraints on fiscal policy are also present in other countries, most of the academic and policy debate on constraints has remained focused on the EMU experience and the very strict framework of fiscal discipline by the member countries of the euro area. This framework, based on numerical limits to budget deficits, has been heavily criticised for being too simple, lacking a proper economic logic and imposing significant costs on the performance of these countries. This debate has led to a variety of proposals to reform and change the current rules of the Stability and Growth Pact. Many of the proposals to improve the current system consist of making these rules more sophisticated.

3. There are several dimensions along which the current rules can be modified: giving proper weight to the debt-to-GDP ratio; taking better account of cyclical conditions; taking into consideration differences in growth rates or initial conditions and, finally, leaving investment outside of the budget, because of the long-term nature of this expenditure. This last proposal is not new, as it relates to the accounting principle that capital expenditures need to be kept outside of the current budget calculations, as in Musgrave (1939) and as practised by several US states in the form of capital budgeting.

1. This paper was prepared for a seminar on fiscal rules which took place at the OECD Headquarters on 12 October, 2005. The author is a professor of Economics at INSEAD in Fontainebleau. He would like to thank Robert Price and Ilian Mihov for helpful comments and suggestions. He also wishes to acknowledge the secretarial help from Paula Simonin, Sandra Raymond and Veronica Humi. The views expressed in the paper are those of the author and do not necessarily coincide with those of the Economics Department of the OECD. 
4. This paper reviews the arguments about the need to make budget rules and constraints more sophisticated by having a differential treatment for investment. The paper starts by justifying the need for fiscal policy rules. There is by no means a consensus around this proposition and that is why clarity is needed before moving to the central question of why sophisticated rules make sense. The second part of the paper discusses in detail the costs and benefits, as well as implementation issues of separating investment from standard budget constraints.

\section{The debate on fiscal policy constraints}

5. The debate on the costs and benefits of fiscal policy rules is a complex one, as it deals with a variety of economic issues for which there is no clear consensus. There are at least two levels of the discussion where there is disagreement and often a lack of clarity in the debate. The first relates to what constitutes good (or bad) fiscal policy. Once this is defined, the debate can move to the second issue of how to build fiscal policy rules that are optimal. Normally this is expressed, first, by highlighting deviations from optimality or, in other words, characterising bad fiscal policy (or what can be referred to as the bias of fiscal policy) and then analysing how different rules or institutional settings affect fiscal policy outcomes. What matters is the extent to which they correct those biases and whether they do so at a minimum cost. For example, strict balanced budget rules are very effective in controlling the level of indebtedness of governments, but they impose large costs in terms of lack of flexibility when it comes to dealing with business cycle fluctuations. In the next sections we review the main arguments and evidence regarding each of these two issues before we look at the proposals for making simple rules more sophisticated.

\subsection{Why constrain fiscal policy?}

6. While there seems to be a growing consensus that, if left alone, policy makers will make fiscal policy decisions far from their optimal level, there is no clear agreement on what constitutes poor fiscal policy management and, more importantly, what its costs are. There are several biases that have been identified in the literature.

a)

Volatile fiscal policy

7. Discretionary changes in fiscal policy have an effect on macroeconomic outcomes and, as a result, bring undesirable volatility to the economy. Examples of discretionary fiscal policy can be changes in taxes or spending around election times (either for re-election purposes or because of ideological changes in the government). They can also be the result of other political events that lead to a demand for different levels of government spending or taxation (e.g. the increase in government spending around the process of German unification). Furthermore, such changes can occur because, as Stokey (2002) argues, not all governments are "as benevolent and clever as a Ramsey government". Incompetent or greedy politicians can generate substantial volatility in fiscal policy instruments.

8. The empirical evidence on discretionary fiscal policy leads to two main conclusions. First, there are significant politically-motivated changes in fiscal policy. Using data for a large sample of countries, recent works by Persson (2001) and Shi and Svensson (2001) present convincing evidence in favour of an opportunistic political business cycle. Second, the macroeconomic effects associated with these changes are large. There is also a growing literature that has documented the effects of exogenous changes in fiscal policy (Blanchard and Perotti, 2002, Fatás and Mihov, 2001 Burnside et al. 1999, Mountford and Uhlig, 2002, Perotti, 2004 or Galí et al. 2002). This literature presents a dynamic analysis of the effects of discretionary changes in fiscal policy on output, consumption or investment. The results are consistent in displaying strong evidence that these discretionary changes have a non-trivial effect on business cycle fluctuations. 


\section{ECO/WKP(2005)53}

\section{b) Procyclical fiscal policy}

9. The second bias that can be harmful for the economy is procyclical fiscal policy. In response to economic fluctuations, fiscal policy should be countercyclical, i.e. in order to smooth out fluctuations in income, budget balances should increase in booms and decrease in recessions. There is evidence however, that in many cases fiscal policy behaves in a procyclical manner as in good times spending increases in excess of the increase in taxes. The reason is that politicians misinterpret cyclical increases in revenue as structural; they may then cut tax rates or increase spending. Most Latin American economies, for example, display procyclical fiscal policy as documented in Gavin and Perotti (1997) and explained in terms of the voracity effect in Tornell and Lane (1999). The evidence for OECD and European economies is somewhat mixed. While there is some evidence of procyclical behaviour, in most cases policy is either acyclical or only slightly countercyclical. Lane (2003) and Wyplosz (2002) present evidence on the cyclical properties of fiscal policy for this group of countries and recently the European Commission in its analysis of EU members' budgetary plans has stressed the importance of avoiding procyclicality in fiscal policy.

\section{c) Excessive deficits and unsustainable budgetary plans}

10. The build up of public debt in most industrial countries after the mid-1970s and the difficulty of some developing countries to contain government indebtedness, has led to a large literature on the bias towards large deficits and excessive debt. Initially the focus was on the risk of monetisation of the debt. Later, as more and more central banks became independent and as real interest rates increased in the 1980s, the focus shifted to the issue of sustainability. This bias is a result of the fact that governments do not internalise fully the cost of additional debt. Persson and Tabellini (2000) summarise some of the main theoretical arguments of this literature. Most of these arguments are indeed related to the "dynamic common-pool problem" where different groups (parties in a coalition, or spending ministers) decide on part of public spending. This decentralised process often leads to excessive spending. Another reason for a transitory accumulation of debt is the postponement of fiscal adjustment after a cyclical downturn.

d)

Intergenerational unfairness/inequity

11. There is a fourth cost of poor fiscal policy which is unrelated to macroeconomic outcomes. The short horizons under which governments and politicians operate, and the fact those future generations cannot participate in the political process, can result in excessive deficits in the present that build up public debt and pass it on as a burden to future generations. It is necessary to stress that this bias is different from the previous one. While both are associated with large deficits, the costs associated with the first are purely macroeconomic while for this the bias can only be understood in the context of intergenerational equity.

\subsection{Why do we care about these biases?}

12. What are the macroeconomic effects of the four biases described above? The first two biases (volatile and procyclical fiscal policy) can be seen as having similar macroeconomic consequences. In both cases governments set a fiscal stance that is not appropriate given the cyclical position of the economy. In that sense, procyclical fiscal policy can be seen as an additional source of fluctuations in output because it reduces the effectiveness of automatic stabilisers (as argued by Melitz, 2000 or Perry, 2003).

13. In the case of the third bias (excessive deficits) it can be argued that it might also lead to additional volatility, even if it does so at a different horizon. There are two scenarios to be considered: the accumulation of debt leads either to default or to a large fiscal adjustment in order to return to a sustainable path. In both cases we expect negative effects on economic volatility and the business cycle as a consequence of the crisis or the large fiscal adjustment. Therefore, even if the notion of excessive deficits is one that refers to long-term sustainability, in many cases the build up of excessive deficits leads to 
scenarios that can be a source of business cycle volatility. For a longer and more general discussion of the welfare costs of excessive deficits see Fatás et al. (2003).

14. If we accept the idea that the main cost of the first three biases is additional output volatility, how large is this cost? Does it simply represent an increase in uncertainty or does this translate into longer-term effects on output growth rates? Although the link between volatility and growth is easily found in the policy literature (e.g. that volatility leads to lower growth, see Perry, 2002), the initial empirical evidence was mixed. However, recent studies show that fiscal policy volatility translates into lower growth (see Fatás and Mihov, 2005).

15. Output volatility is not the only consequence of bad fiscal policy. This is very clear when it comes to the last two biases, especially intergenerational inequity. In this case, the costs are more subtle and they have to do either with microeconomic distortions, such as lack of tax smoothing or simply with fairness arguments. Measuring the size of these costs is much more difficult and can only be done with complex intergenerational accounting methods.

\subsection{How can fiscal policy biases be avoided?}

16. There is plenty of empirical support for the existence of the four biases described above. Given the large costs that they impose on the economy, there has been a long literature trying to understand how different institutional settings can affect the behaviour of fiscal policy and reduce its biases. There is ample evidence in the literature that the institutional setting in which fiscal policy operates does indeed affect its behaviour. Whether we care about excessive deficits or about volatile fiscal policy, there is plenty of evidence that political and budgetary processes and rules have an effect on fiscal policy outcomes. In general, from an empirical point of view, most of the experiments we have seen are about imposing some form of institutional constraint on the budget or a component of the budget. These constraints do restrain the behaviour of governments but they can also have undesirable side effects. In the trade-off between the positive effects they have on budget outcomes and the costs they impose because of their restrictiveness, there are several optimality principles around which the literature seems to have found a consensus. In summary, the following are the guidelines under which constraints and fiscal policy rules should be designed.

The need to establish transparent goals

17. There is a need to make explicit the goal that the fiscal rules are designed to achieve. Following our previous arguments, we can think of fiscal rules that address some or all of the biases that we have identified. Is the main goal to ensure sustainability? Or is it to avoid procyclicality and additional volatility? It is fair to say that most of the recent cases in which we have seen the adoption of a fiscal rule, this adoption tends to originate in the need to ensure credibility from a longer-term perspective and to limit the possibility of default or, at least, the necessity of large fiscal adjustments in response to exploding debt. For example, the Maastricht Treaty and the Stability and Growth Pact (SGP), which set strict numerical limits on budget deficits and debt for member countries of EMU, justify these limits with the notion that to safeguard the value and the credibility of the single currency and the European Central Bank, there is a need to protect monetary policy from pressures coming from unsustainable debt paths. The notion of procyclicality or even excess volatility of fiscal policy seems absent from both the Treaty and the Pact.

18. Despite the apparent clarity in the original goal, the recent debate on the reform of the SGP shows that there is confusion about the final objective of this institutional framework and, as a result, different proposals are defended or criticised from different angles. For example, if one seeks a narrow goal, such as enforcing long-term sustainability, limits on debt or deficits might be appropriate. But if the goal is broadened to include elements of intergenerational fairness or tax smoothing, then numerical rules 


\section{ECO/WKP(2005)53}

are unable to take care of circumstances that cannot be foreseen when the rule is established. Moving forward with this debate requires clarity and transparency regarding the ultimate objectives of the fiscal policy constraints.

\section{b) The trade-off between flexibility and discipline}

19. Even if the benefits of discipline are accepted, the lack of flexibility implied by strict fiscal rules cannot be ignored. It is fair to say that most of the opponents of the adoption of fiscal rules base their arguments on the assumption that restricting fiscal policy increases output volatility (see Levinson, 1998). But the simplicity of rules can also lead to biases in the composition of government expenditures, causing a relative increase in current expenditures relative to investment. ${ }^{2}$

20. Because of these arguments, recent proposals have emphasised the need to move away from simple rules to "smart" and more complex ones along two dimensions. First, there is a need to define targets for budgets which are cyclically adjusted. Although this might be an obvious point, as a counter example, it was not considered in the original Maastricht Treaty. Over time, and given the increasing sense of failure of the system, the European Commission introduced flexibility in the way these balances were computed and moved towards a systematic application of the concept of structural balances in EMU. This is the approach of the Chilean system that targets a 1 per cent structural surplus (as a ratio to GDP) and therefore allows for balances to fluctuate during the cycle. While this is a fundamental issue, it is very much of a technical nature: how to measure the fiscal stance.

21. The second dimension where simple rules can be made more sophisticated deals with the different nature of different components of the budget. As noted, there is a potential composition bias associated with rules that only look at budget balances. If this is the case, rules should not apply uniformly to all items in the budget. Most proposals along this line focus on investment and argue that it should be treated differently, or simply excluded from the constraints. Of course, removing investment from the budget can also be supported by other arguments, such as intergenerational fairness, which are independent of the possibility of composition biases as a result of fiscal consolidations. Excluding investment from the budget constraints is normally referred to as the "golden rule" and such exclusion is embedded, for example, in the German constitution and in the current fiscal framework followed by the UK government. A variant of this proposal has recently been put forward by Blanchard and Giavazzi (2004) in the context of the SGP. An alternative, but related, approach is the Permanent Balance Rule proposed by Buiter and Grafe (2002), which emphasises differences across countries in terms of initial conditions and tries to move away from the arbitrariness of any numerical target.

c)

Rules need to be enforced

22. For a rule to be effective, it needs to be easily enforced. While this is an obvious point it seems to be one of the biggest difficulties of the recent implementation of fiscal policy rules. What should be stressed is that enforcement cannot be dissociated from some of the previous characteristics of what constitutes an optimal rule. For example, a rule that is too rigid and not flexible enough might suffer serious problems of enforceability. The bigger obstacles in terms of enforceability are political economy arguments, combined with the fact that commitment to the rules is not perfect. In addition, enforceability can also be impaired by more technical problems about the ability to measure some of the parameters on which the rule is based.

2. We will look at this argument in detail below. 


\subsection{Explicit versus implicit constraints}

23. When designing a system of constraints on fiscal policy, the starting point tends to be that of numerical rules on either the budget balance, or a subset of the budget balance. There are, however, other ways of imposing constraints on governments that are not explicit but rather implicit, being based on institutional arrangements regarding the decision-making process. There is plenty of evidence that these arrangements can be as effective as strict numerical rules. Empirical studies by von Hagen (1992), von Hagen and Harden (1995), Alesina and Perotti (1996) von Hagen et al. (2002), and Fatás and Mihov (2003), show that the design of budget processes (e.g. the relative power assigned to the Finance Minister and the importance given to budgetary targets), or different degrees of political constraints (e.g. number of veto points in the budgetary decisions) can have a significant impact on fiscal outcomes such as the budget deficit, the success of fiscal consolidations and the volatility of discretionary changes in the budget. As a result, we are seeing an increasing number of academic proposals that take this idea seriously and even a small number of countries that have partially implemented these solutions. For example, von Hagen and Harden (1995), Eichengreen et al. (1999) or, more recently, Wyplosz (2002) or Fatás et al. (2003) all propose the creation of independent committees or boards that ensure that fiscal policy is consistent with the goals set by the political power.

24. Does an institutional solution to the credibility problem of fiscal policy sound unrealistic? The experience of monetary policy in the past decades shows that this is not the case. The analysis of monetary policy in the 1970s and 1980s showed that discretion in monetary policy leads to an inflation bias and to unnecessary volatility. The outcome of this analysis was not a rigid rule (such as a constant money growth target) but an institutional reform that delegates monetary policy to an independent central bank that has no reason to produce any bias in the conduct of monetary policy. Of course, there is a clear mandate (e.g. an inflation target) but it is expressed as a medium-term goal (allowing for short-term flexibility) that could be similar to a sustainability mandate expressed in terms of a debt-to-GDP ratio in the case of fiscal policy. The experience of the past 20 years, in many countries, shows that such an institutional arrangement can impose discipline without eliminating flexibility.

25. Is an institutional solution implementable when it comes to fiscal policy? Here one needs to be careful of taking the parallel of monetary policy too far. There are many ways to introduce discipline in fiscal policy through institutional arrangements that are very far from taking the power of decision away from governments (as is the case with independent central banks and monetary policy). In most of the empirical results that show that institutional and political constraints are effective in providing the necessary fiscal policy discipline, this was not done by heavy institutional design but simply by the natural constraints imposed by political and budgetary processes. Even in most of the proposals about the creation of national fiscal policy boards, the role of these boards is not to control the policy instrument (budgets); rather it is the exercise of control over the use of that instrument by governments that results in an effective constraint on fiscal policy. For a detailed analysis of how this could be implemented we refer the reader to Fatás et al. (2003). There are, also, today many examples of institutional constraints on governments both at the supranational and national level. We can think of the IMF or the European Commission playing a strong monitoring role when it comes to national fiscal policy of the countries they oversee. While their actions might not be as effective as one would like, their monitoring is likely having an effect on fiscal policy outcomes. At the national level, there are also examples of committees or boards that oversee and monitor budgetary plans. There are such committees or councils in Belgium, Austria or Sweden. In other cases, the institutional arrangement comes from budgetary processes in which the finance minister has the power to set a ceiling for the annual deficit at the outset of the process (see von Hagen et al., 2002). 


\section{ECO/WKP(2005)53}

\section{Excluding investment from fiscal policy constraints}

26. It is clear from our previous analysis that a crucial issue in the design of fiscal policy rules is how to deal with public investment. In this section we focus our analysis on the proposals to leave investment outside the constraints of fiscal policy (Blanchard and Giavazzi, 2004 or Buiter and Grafe, 2002 among others). Most of the arguments used in defence of these proposals are based on the fact that public investment is different from other forms of expenditure, because the services rendered by capital are spread over many years or even generations and because, contrary to current expenditures, investment can generate increases in private-sector output (and possibly tax revenues). Despite the similarities in these proposals, the economic arguments for excluding investment from budget calculations are many and relate to several of the fiscal policy biases described in previous sections. We first discuss how the "golden rule" relates to the four fiscal policy biases and then we discuss how close it is to being an optimal rule.

\subsection{The performance of a "golden rule"}

27. Given our description of the four potential fiscal policy biases, how successful can the "golden rule" be in correcting those biases and how does it compare with the alternatives? The concept of the "golden rule" is, in principle, consistent with many different approaches to constraining fiscal policy. It can apply whether or not there is an adjustment for cyclical conditions or whether the target is expressed in terms of the deficit or the debt. What matters is that investment is left out of the constraints. Therefore, when comparing it with alternatives, the question is to what extent excluding investment makes a particular rule more effective, by correcting the biases described above, or less costly in terms of side effects.

28. It is fair to say that a "golden rule" does not explicitly address the issue of volatile or procyclical fiscal policy. If anything, by relaxing the restrictions on one of the components of the budget, it makes it easier for governments to introduce discretion in their conduct of fiscal policy, possibly adding volatility to the business cycle. In fact, there is evidence that public investment is more volatile than public consumption, which would be an additional reason to constrain investment. The same is true with respect to the bias of excessive debt. If anything, by excluding investment, there is less strict control of the overall level of deficits and gross debt. On the fourth bias, however, the "golden rule" seems to be a must. If the goal of constraining fiscal policy is to introduce intergenerational equity in the budget process, there is a need to have some sort of intergenerational account of the services that are provided by government spending and then allocate taxes accordingly.

29. In summary, when the "golden rule" is tested against the four biases that we have identified, the only strong argument that can be made is that it is designed to deal with the issues of intergenerational equity. When it comes to the other three biases there is no clear direct connection to them and, if anything, by relaxing the constraint we might be reducing the level of discipline. However, we should not forget that there is an additional test that any fiscal policy rule has to pass. A rule has to be efficient in the sense that the costs associated with its implementation outweigh its benefits, and this will also be linked to issues of enforceability. This is where additional arguments can be found in favour of a "golden rule". It is not so much about the way in which it addresses the biases but about the fact that its implementation reduces the cost of fiscal policy constraints or, alternatively, it constrains fiscal policy in a more efficient manner. Both arguments help the enforceability of the rules. They are discussed in detail in the next section.

\subsection{The benefits of a "golden rule"}

30. The "golden rule" can be seen as a refinement of a balanced budget rule. Reviewed below are the main arguments in favour of this refinement and a quick overview of their empirical validity is provided. 
1. It provides a proper accounting framework. Capital expenditures are different from current expenditures. This is an argument based on the principle that investment is different in nature from government consumption. It receives support from the fact that it is indeed common (accounting) practice, certainly among private corporations, to separate current and budget expenditures and to include only capital depreciation in the current budget. This argument is in some sense present in all the arguments that follow, as stating the different nature of capital spending is a first step towards justifying its different accounting treatment.

2. It provides a framework to think about debt sustainability. If we accept that one of the goals of fiscal constraints is to provide a framework for assessing the sustainability of budgetary plans (to address the excessive deficit/debt bias), then a correct definition of sustainability requires proper accounting of capital expenditures. Given that net investment represents an increase in the assets of the government, then it needs to be removed from the borrowing constraints even if the goal is to keep net debt equal to zero. This is the point raised by Blanchard and Giavazzi (2004). By having government borrowing equal to net investment the debt of the government converges to the stock of public capital. This has a clear economic meaning, unlike overall constraints in the budget deficit, which will push the debt-to-GPD ratio to zero (or to an arbitrary number without an economic significance). There is, however, the remaining issue of whether gross public debt contains information that is relevant. It is probably the case for emerging countries where governments face borrowing constraints associated with the size of gross debt, which indicates the total amount of borrowing done by governments. Financial markets are likely to ignore the value of the government assets when judging the ability of the government to pay back the debt. This raises, once again, the issue of understanding what the objectives are when setting a limit to government debt. If the objectives are related to intergenerational equity then this argument is irrelevant. If the objectives are, however, related to allowing a constrained government access to international financial markets, then gross debt might be a more relevant indicator than net debt. In summary, the distinction between gross and net debt is an important one that requires some attention when assessing budgetary plans. How to interpret both numbers and its implications for sustainability is, however, a complex task that requires different approaches depending on the country under consideration.

3. It provides transparency. This follows immediately from the first two points. Given their different nature, only by separating current and capital expenditures can governments provide a clear picture of the fiscal policy stance, one that is both accurate and transparent. While transparency is a virtue in itself, within the context of fiscal policy rules, and as argued above, transparency is crucial to making a rule successful. A clear assessment of the fiscal stance and how it relates to economic conditions seems to be a condition for a rule to be implementable and credible. How exactly this argument becomes operational is an open question. The fact that one needs to account properly for different forms of expenditures does not mean that capital expenditures should not be constrained. One could imagine different but possibly similar constraints on both types of expenditures even if they are accounted for in different budgets.

4. It makes for intergenerational equity. This is possibly one of the strongest arguments and it is independent of any of the other more macroeconomic arguments. As long as the constraints on fiscal policy are motivated, fully or partially, by intergenerational fairness arguments, then there is a clear need to differentiate between expenditures that benefit the current generation and those whose benefits will be spread over the current and future generations. While some forms of expenditure should be financed by current revenues (so that they are paid by the current generation), there is no reason to force the current generation to pay for spending that will render services over a long horizon. Under this scenario, government borrowing should match net investment (as in the proposal of Blanchard and Giavazzi, 2004). 


\section{ECO/WKP(2005)53}

5. Investment might pay for itself. If rules are designed to ensure the sustainability of budgetary plans then public investment, to the extent that it can lead to higher returns, higher output and future tax revenues, can pay for itself and should be treated differently. This is a straightforward argument but requires empirical validation. To be valid, it has to be the case that the combination of financial returns and tax revenues associated with the increase in output generated by the investment project are larger than the initial investment. This is a very strong assumption. It requires public investment multipliers which are large enough to generate the additional tax revenues needed to fund the project. The evidence is clearly against this hypothesis, at least in its strongest form. First of all, although some early estimates of the returns to public investment were very high (Aschauer, 1989), later estimates showed that these returns are not as high as initially thought (Fernald, 1993). While there might not be full agreement on these estimates, even the highest estimates in the literature are too low to generate sufficient future output and taxes to pay for the initial spending. This is confirmed by recent studies of the dynamic effects of fiscal policy on output, where public investment is shown to have a small (and, in some cases insignificant) effect on output. If anything, it seems that the multiplier of public investment is lower than the multiplier associated with other forms of government expenditure (Perotti, 2004 or Fatás and Mihov, 2001). The counterargument, that this analysis does not capture the social return on public investment, is not valid. While it might justify the need to fund public investment, the social return on investment does not lead to future taxes that can guarantee the stability of public finances.

One has to be careful taking this argument too far. True, public investment might not pay for itself but this does not mean that the "golden rule" will lead to default. As long as proper care is taken of depreciation of public capital and its financial returns, sustainability is guaranteed (in terms of net debt). For example, in the proposal of Blanchard and Giavazzi (2004), debt sustainability is ensured by the fact that the depreciation and the financial return on capital are taken into account. In the long run, and as long as governments follow their rule, the stock of public debt will equal the stock of public capital. And the rule could be modified to make this condition stricter so that debt is kept at a lower level. There are, of course, many implementation issues that might bring additional complications, but we ignore them for the moment and will come back to them later in the paper.

6. Blind constraints on fiscal policy impose biases in public spending. Because of the constraints imposed on public finances by balanced budget rules, there can be a bias towards cutting public investment beyond what is optimal, to the benefit of current expenditures that are more difficult and politically painful to cut. This effect might be more prominent when fiscal policy rules, or simply ambitious targets, are achieved through a large fiscal consolidation. The idea is intuitive, as cutting certain large investment projects that might have a return only in the long run might be the easy way out for governments to live by the restrictions imposed by fiscal rules, or to achieve a quick numerical success during consolidation plans. The evidence here is mixed. There seems to be strong evidence that fiscal consolidations have had a negative effect on public investment (infrastructure) and a negative effect on growth for developing countries, especially Latin America (Calderón et al. 2003 and Calderón and Servén, 2003). However, when it comes to the recent EU experience under the Maastricht Treaty and the SGP, the evidence is less clear. While there has been a decrease in public investment as a result of the run-up to EMU, there is disagreement on whether this decrease is due to EMU or to a wider trend that has also been witnessed in similar countries (see Peree and Valila, 2005 or Galí and Perotti, 2003).

7. For fiscal consolidations to be successful and survive public (and political) scrutiny they should not have strong contractionary effects on output. There is strong evidence that in the case of the European economies recent consolidations have been successful only in those countries where 
GDP growth has been healthy. In countries with stagnant economies or where growth has been weak, consolidations have failed or have not reached their targets. It is, of course, very difficult to distinguish empirically between cause and effect. Numerically, faster GDP growth will always help to keep the debt-to-GDP ratio under control. The key question is to what extent the composition of the fiscal adjustment has had any effect on the growth performance of the economy. There is support for the idea that adjustments that have relied on public expenditure cuts have been more successful and expansionary than those relying on tax increases, but the exact composition of the expenditure cuts does not seem to be related to how successful the consolidation has been (see Fatás et al. 2003). In some sense, the argument that the composition matters depends on the same assumptions used by the logic that investment pays for itself. To the extent that investment has a strong effect on output, a fiscal consolidation that imposes a large fall in public investment would be less likely to succeed. It is therefore necessary to exclude public investment from the standard numerical fiscal policy rules to protect it from unnecessary cuts.

8. Ensuring popular support. Any restriction on fiscal policy needs to find enough political support to be sustainable and enforceable. Given the different nature of public investment and the fact that it is perceived by some as a productive investment, leaving it out of the strict constraints on fiscal policy rules might look more reasonable in the eye of the public and therefore find less political opposition. This argument relates to the previous one but it only requires for the perception to exist.

\subsection{Some implementation issues}

31. Our discussion above has offered arguments in support of properly accounting for investment when establishing fiscal policy constraints. The arguments are in many cases independent of the constraints themselves, i.e. the proper accounting treatment of investment might be desirable even for an unconstrained government. However, if the main reason for constraining fiscal policy is intergenerational equity, then clearly these constraints need to take into account the different nature of capital expenditure. Even in such a case, there are many issues in the implementation of such a policy that need to be considered before drawing a conclusion about its overall benefits.

How should the rule be expressed?

32. Let us make a starting assumption that we are considering the case of a government facing a balanced-budget constraint (similar arguments apply to the case of a constraint on the overall deficit, such as in the SGP). Let us ignore details such as whether or not figures are cyclically adjusted, which are irrelevant to this issue. The question we face is how investment should be dealt with in that environment? Should it simply be removed from the constraint or should the constraint be modified? There is no answer to this question unless we first decide on the motives for the exclusion of investment. If the logic is based on intergenerational equity and on the principle that investment is different in nature, then borrowing should be allowed as long as it finances net investment. This is the proposal by Blanchard and Giavazzi (2004) and it comes straight from the principle that net investment increases the value of the assets of the government.

33. If the reason why governments are constrained is simply to avoid an increase in the gross public debt (for fear that it will displace private investment or might lead to a financial crisis) then borrowing should be allowed to finance investment as long as it will pay for itself in the future. This implies that the net present value of future taxes or revenues generated by the investment project equals the value of the investment. As argued above, given estimates of returns on public investment, it is very likely that the rule is not too different from a strict balanced-budget rule. 


\section{ECO/WKP(2005)53}

34. In the case where the argument is that investment should be protected from borrowing constraints because of a potential composition bias in fiscal consolidations there is no straightforward rule. As the argument depends on the importance of investment, its returns (financial and social) and its contribution to growth, all of them relative to other forms of government spending, the rule will be dependent on many variables and factors that are likely to be country and time-specific.

35. In reality, it is likely that the reasons for keeping investment out of the regular budget are a combination of the three reasons above. This, combined with the fact that many of the parameters to be used can only be imprecisely estimated, makes a modified balanced-budget rule very difficult to implement. Moreover, it is likely to lead to problems of time consistency as circumstances and estimates change.

b) Can depreciation be properly measured? How do we estimate the returns on investment? What counts as public investment?

36. These are all technical questions regarding how the rule is implemented. There is no easy answer to any of them. At the same time, the fact that there is no easy answer does not mean that finding one is not possible or that such a rule cannot be implemented. For example, one can look at the experience of US states that have applied capital budgeting for many years. The definition of capital expenditures that each of the US states uses is different but there are many similarities and, despite the difficulties, it is clear that the implementation is feasible and, to some extent, successful.

37. Technical difficulties in the accounting of capital or the calculation of a depreciation rate also cannot justify a quick rejection of the "golden rule" proposal. However, they highlight the difficulties in establishing quick and simple rules to deal with public investment. This brings us back to the discussion earlier in the paper about explicit versus implicit constraints. It is clear that calibrating all the above difficulties to produce a simple numerical rule that can be applied to many countries and over different periods of time is a daunting task. An alternative is to agree on the principles and create an institutional environment (e.g. a public investment agency) that oversees the process and can use judgment over and above what a simple numerical rule can do.

c) Can it be an open door to creative accounting?

38. It is true that any exclusion of a government spending component from the constraints faced by governments can open the door to creative accounting as a means of relaxing the constraints. At the same time, this is also an argument against any refinement of a very strict numerical rule. But given that there is a growing consensus to move away from strict numerical rules (whether through cyclical adjustments, special circumstances or a golden rule) this criticism, while valid, applies to all these refinements and simply calls for a more transparent and consistent set of accounting principles together with a process for monitoring and enforcing fiscal policy rules. As argued before, leaving investment out of the current budget is one step in the direction of providing more transparency to the process. As empirical evidence, there is little evidence of US states abusing capital budgeting and off-budget items to avoid balancedbudget constraints (see Bohn and Inman, 1996 and Sorensen et al. 2001).

\section{Conclusions}

39. The failure of simple numerical rules to constrain the behaviour of fiscal policy in an efficient and sustainable manner has led to a debate on the need to make those rules more sophisticated and flexible. One of the dimensions that has received more attention is the need to exclude investment from any fiscal policy rule, what is commonly known as the adoption of a "golden rule". 
40. Our point of departure has been that discussions on the appropriateness of a "golden rule" (or for that matter any other fiscal policy rule) can only happen once the goals and objectives of constraining fiscal policy are made clear. There are scenarios where excluding investment from balanced-budget rules is clearly not desirable. For example, if the objective is simply to keep the gross debt under control, to avoid tensions in financial markets as governments need to refinance their debt, then excluding investment cannot be justified. In that scenario, the only reason to deal differently with investment would be if it paid for itself (i.e. the increase in output and taxes associated with public investment was high enough to fund the required capital). But there is overwhelming evidence that this is not the case as public investment multipliers are low.

41. However, there are other scenarios and arguments in favour of not including investment in the regular government budget. The main argument is that excluding investment is the only way to guarantee intergenerational equity. This argument cannot be easily dismissed as it is likely that the adoption of fiscal rules (such as balanced-budget rules) is partly motivated by intergenerational issues. The second set of arguments in favour of a "golden rule" highlights the need for transparency and clarity in any fiscal rule if it is to be sustainable and politically accepted. In terms of transparency, it is clear that, conceptually, investment should be dealt with separately. This is an accounting principle which is unrelated to any form of fiscal policy constraint. On top of that, some public investment is likely to lead to high economic and social returns and, because of its long-term nature, might be negatively affected by fiscal consolidations. In other words, as long as we accept the need for fiscal constraints, their sustainability will depend on their transparency, perceived fairness, flexibility and ability to minimise the costs associated with them. Excluding investment from balanced-budget rules adds to all those dimensions and would therefore help to ensure the sustainability of the rules themselves.

42. One counterargument is that while this separation of regular and capital budgets might be conceptually appealing, there are many implementation issues that might reduce the effectiveness of the constraints and might indeed create less transparency and credibility. Without denying these issues, it is clear that these criticisms apply to any numerical rule and not only to the "golden rule". In fact, one can take this logic even further and argue that the only way to provide a transparent and credible framework for fiscal policy is by making the difficulties and complications of dealing with investment explicit. If not, they will reappear in an implicit manner and weaken the discipline imposed by the constraints. The best way to illustrate this argument is to look at how the tensions of the SGP have been resolved by amendments that allow for the exclusion of certain expenditures from the rule, but this has happened without providing a proper framework for these exemptions to be made.

In order to enhance the growth-oriented nature of the Pact, major structural reforms which have direct long-term cost-saving effects, including by raising potential growth, and therefore a verifiable impact on the long-term sustainability of public finances, should be taken into account when defining the adjustment path to the medium-term budgetary objective for countries that have not yet reached this objective and in allowing a temporary deviation from this objective for countries that have already reached it. In order not to hamper structural reforms that unequivocally improve the long-term sustainability of public finances, special attention should be paid to pension reforms introducing a multipillar system that includes a mandatory, fully funded pillar, because these reforms entail a short-term deterioration of public finances during the implementation period. COUNCIL REGULATION (EC) No 1055/2005 of 27 June 2005 amending Regulation (EC) No 1466/97 on the strengthening of the surveillance of budgetary positions and the surveillance and coordination of economic policies.

43. This is a clear illustration that simple numerical rules, which are not sufficiently transparent and do not allow for the flexibility demanded by the political process are not time consistent and politicians will always find ways around them. And because amendments or modifications to the rule are not explicit and open to discretion and future changes, it creates an environment that is likely to lead to excessive 


\section{ECO/WKP(2005)53}

discretion and the exercise of "creative accounting". Our argument is that, by recognising explicitly the different nature of long-term expenditures or investment, a rule such as the "golden rule" would improve the discipline of fiscal policy.

44. Finally, it is clear that strict numerical rules will always struggle with trade-offs between simplicity and richness (or flexibility). The quotation above is a clear example of how any attempt to stick to simple numerical rules is likely to fall apart as time passes and circumstances change. While making these rules sophisticated is a welcome exercise, it moves us away from simplicity (one of the biggest virtues of numerical rules). A "golden rule" also comes with its complications and implementation issues and it is likely to suffer from the same trade-off. This brings us back to the debate about numerical rules versus institutional arrangements to constrain government behaviour. And we need to stress that by institutional arrangements we do not mean delegating fiscal policy decisions to independent bodies but simply putting processes around the budgetary decisions that can lead to the desired outcome. While it is true that conceptually it is more difficult to devise institutional reforms than to specify simple numerical rules, this cannot be an excuse not to make progress in this direction.

45. As an example, and in the case of a "golden rule", a public investment agency that would be responsible for the type of analysis that is required to make it operational would be a very simple and practical example of how the institutional setting could be improved over what a simple rule can deliver. By introducing judgment and monitoring via the creation of independent agencies, policy makers could move their decisions away from the tradeoff between simplicity and flexibility. By doing so they would be providing an institutional environment that ensures discipline without losing too much in terms of flexibility. 
ECO/WKP(2005)53

\section{REFERENCES}

Alesina, A. and R. Perotti (1996), "Fiscal Expansions and Adjustment in OECD Economies," Economic Policy, Vol. XXI.

Aschauer, D. (1989), "Is Public Expenditure Productive”, Journal of Monetary Economics, No. 23.

Blanchard, O. and R. Perotti (2002), "An Empirical Characterization of the Dynamic Effects of Changes in Government Spending and Taxes on Output," Quarterly Journal of Economics, Vol. LXVII.

Blanchard, O. and F. Giavazzi (2004), "Reforms that Can be Done: Improving the SGP through a Proper Accounting of Public Investment", CEPR Discussion Paper Series, No. 4220.

Bohn, H. and R. Inman (1996), "Balanced-budget Rules and Public Deficits: Evidence from the U.S. States," Carnegie-Rochester Conference Series on Public Policy, No. 45.

Buiter, W. and C. Grafe (2002), "Patching up the Pact: Some Suggestions for Enhancing Fiscal Sustainability and Macroeconomic Stability in an Enlarged European Union", CEPR Discussion Paper Series, No. 3495.

Burnside, C., M. Eichenbaum and J.D.M. Fisher (1999), “Assessing the Effects of Fiscal Shocks", NBER Working Papers, No. 7459.

Calderón, C. and L. Servén (2003), “The Output Cost of Latin America's Infrastructure Gap”, Central Bank of Chile Working Papers, No. 186, www.bcentral.cl/esp/estpub/estudios/dtbc/pdf/dtbc186.pdf.

Calderón, C., W. Easterly and L. Servén (2003), "Infrastructure Compression and Public Sector Solvency in Latin America", Central Bank of Chile Working Papers, No. 187, www.bcentral.cl/esp/estpub/estudios/dtbc/pdf/dtbc187.pdf.

Eichengreen, B., R. Hausman and J. von Hagen (1999), "Reforming Budgetary Institutions in Latin America: The Case for a National Fiscal Council", Open Economies Review, No. 10.

Fatás, A. and I. Mihov (2001), "The Effects of Fiscal Policy on Consumption and Employment: Theory and Evidence," INSEAD Working Papers, No. 78.

Fatás, A, and I. Mihov (2003), “The Case for Restricting Fiscal Policy Discretion," Quarterly Journal of Economics, Vol. 118, Issue 3, November.

Fatás, A. and I. Mihov (2005), "Policy Volatility, Institutions and Economic Growth," unpublished manuscript, INSEAD, Fontainebleau, France.

Fatás, A., A.H. Hallet, A. Sibert, R. Strauch and J. von Hagen (2003), "Stability and Growth in Europe: Towards a Better Pact"', Monitoring European Integration, CEPR Monitoring European Integration Series, No. 13, London. 


\section{ECO/WKP(2005)53}

Fernald, J. (1993), "Roads to Prosperity? Assessing the Link between Public Capital and Productivity", American Economic Review, Vol. 89, No. 3.

Galí, J., D. López-Salido and J. Vallés (2002), "Understanding the effects of Government Spending on Consumption," www.ecb.int/events/pdf/conferences/Galietal.pdf.

Galí, J. and R. Perotti (2003), "Fiscal Policy and Monetary Integration in Europe", Economic Policy, No. 37, Blackwell publishing, October.

Gavin, M. and R. Perotti (1997), "Fiscal Policy in Latin America," NBER Macroeconomics Annual, Cambridge, Massachussetts.

Lane, P. (2003), "The Cyclical Behavior of Fiscal Policy: Evidence from the OECD," Journal of Public Economics, Vol. 87, No. 12.

Levinson, A. (1998), "Balanced Budgets and Business Cycles: Evidence from the States", National Tax Journal, Vol. 51, No. 4, December.

Melitz, J. (2000), "Some Cross-Country Evidence about Fiscal Policy Behavior and Consequences for EMU," European Economy, Vol. 2.

Mountford, A., and H. Uhlig (2002), "What Are the Effects of Fiscal Policy Shocks," CEPR Discussion Papers, No. 3338, London.

Musgrave, R., (1939), "The Nature of Budgetary Balance and the Case for Capital Budget", American Economic Review, No. 29.

Peree, E. and T. Valila (2005), "Fiscal Rules and Public Investment”, European Investment Bank, Economic and Financial Report 2005/02.

Perotti, R. (2004), "Estimating the Effects of Fiscal Policy in OECD Countries," Innocenzo Gasparini Institute for Economic Research (IGIER) Working Papers, No. 276, downloadable from www.igier.unibocconi.it.

Perry, G. (2003), "Can Fiscal Rules Help Reduce Macroeconomic Volatility in the Latin America and the Caribbean Region?", World Bank Policy Research Working Papers, No. 3080.

Persson, T. (2001), "Do Political Institutions Shape Economic Policy,” NBER Working Papers, No. 8214, Cambridge, Massachusetts.

Persson, T. and G. Tabellini (2000), Political Economics: Explaining Economic Policy, MIT Press, Cambridge, Massachusetts.

Persson, T. and G. Tabellini (2001), "Political Institutions and Policy Outcomes: What are the Stylized Facts?" CEPR Discussion Paper Series, No. 2872, London.

Shi, M. and J. Svensson (2001), "Political Budget Cycles: Do they Differ between Developed and Developing Countries?", Institute for International Economic Studies (IIES), www.iies.su.se/ svenssoj/pbc1.pdf, Stockholm, October.

Sorensen, B., L. Wu and O. Yosha (2001), "Output Fluctuations and Fiscal Policy: U.S. State and Local Governments 1978-1994” European Economic Review, No. 45. 
Stokey, N. (2002), "Rules Versus Discretion after Twenty-Five Years," NBER Macroeconomics Annual, Cambridge, Massachusetts.

Tornell, A. and P. Lane (1999), “The Voracity Effect,” American Economic Review, No. 89.

von Hagen, J. (1992), "Fiscal arrangements in a monetary union: some evidence from the US", in D. Fair and C. de Boissieuxm (eds.), Fiscal Policy, Taxes and the Financial Systems in an Increasingly Integrated Europe, Deventer: Kluwer Academic.

von Hagen, J. and I. Harden (1995), "Budget Processes and Commitment to Fiscal Discipline”, European Economic Review, No. 39.

von Hagen, J., A.H. Hallett and R. Strauch (2002), Budgetary Consolidation in Europe: Quality, Economic Conditions and Persistence", Journal of the Japanese and International Economies, Vol. 16.

Wyplosz, C. (2002), "Fiscal Policy: Institutions vs. Rules", CEPR Discussion Papers, No. 3238, London. 
ECO/WKP(2005)53

\section{WORKING PAPERS}

The full series of Economics Department Working Papers can be consulted at www.oecd.org/eco/Working_Papers/

465. Fiscal rules for sub-central governments design and impact

(December 2005) Douglas Sutherland, Robert Price and Isabelle Joumard

464. Assessing the robustness of demographic projections in OECD countries (December 2005) Frédéric Gonand

463. The Benefits of Liberalising Product Markets and Reducing Barriers to International Trade and Investment in the OECD

(December 2005

462. Fiscal relations across levels of government in the United States (November 2005) Thomas Laubach

461. Assessing the value of indicators of underlying inflation for monetary policy (November 2005) Pietro Catte and Torsten Sløk.

460. Regulation and economic performance: product market reforms and productivity in the OECD (November 2005) Giuseppe Nicoletti and Stefano Scarpetta.

459. Innovation in the Business Sector

(November 2005) Florence Jaumotte and Nigel Pain

458. From Innovation Development to Implementation: Evidence from the Community Innovation Survey (November 2005) Florence Jaumotte and Nigel Pain

457. From Ideas to Development: the Determination of $R \& D$ and Patenting (November 2005) Florence Jaumotte and Nigel Pain

456. An Overview of Public Policies to Support Innovation (November 2005) Florence Jaumotte and Nigel Pain

455. Strengthening Regulation in Chile: The Case of Network Industries (November 2005) Alexander Galetovic and Luiz de Mello

454. Fostering Innovation in Chile

(November 2005) José-Miguel Benavente, Luiz de Mello and Nanno Mulder

453. Getting the most out of public sector decentralisation in Mexico (October 2005) Isabelle Joumard

452. Raising Greece's Potential Output Growth (October 2005) Vassiliki Koutsogeorgopoulou and Helmut Ziegelschmidt

451. Product Market Competition and Economic Performance in Australia (October 2005) Helmut Ziegelschmidt, Vassiliki Koutsogeorgopoulou, Simen Bjornerud and Michael Wise

450. House Prices and Inflation in the Euro Area (October 2005) Boris Cournède

449. The EU's Single Market: At Your Service? (October 2005) Line Vogt 
448. Slovakia's introduction of a flat tax as part of wider economic reforms (October 2005) Anne-Marie Brook and Willi Leibfritz

447. The Education Challenge in Mexico: Delivering Good Quality Education to All (October 2005) Stéphanie Guichard

446. In Search of Efficiency: Improving Health Care in Hungary (October 2005) Alessandro Goglio

445. Hungarian Innovation Policy: What's the Best Way Forward? (October 2005) Philip Hemmings

444. The Challenges of EMU Accession Faced by Catch-Up Countries: A Slovak Republic Case Study (September 2005) Anne-Marie Brook

443. Getting better value for money from Sweden's healthcare system (September 2005) David Rae

442. How to reduce sickness absences in Sweden: lessons from international experience (September 2005) David Rae

441. The Labour Market Impact of Rapid Ageing of Government Employees: Some Illustrative Scenarios (September 2005) Jens Høj and Sylvie Toly

440. The New OECD International Trade Model (August 2005) Nigel Pain, Annabelle Mourougane, Franck Sédillot and Laurence Le Fouler

439. The French Tax system: Main characteristics, recent developments and some considerations for reform (July 2005) Willi Leibfritz and Paul O'Brien

438. The Effects of EMU on Structural Reforms in Labour and Product Markets (July 2005) Romain Duval and Jørgen Elmeskov

437. Product Market Competition andEconomic Performance in New Zealand (July 2005) Annabelle Mourougane and Michael Wise

436. Getting the Most out of Public Sector Decentralisation in Spain (July 2005) Isabelle Joumard and Claude Giorno

435. Sources of Inflation Persistence in the Euro Area (July 2005) Boris Cournède, Alexandra Janovskaia, Paul van den Noord

434. Measuring Cyclically-Adjusted Budget Balances for OECD Countries (July 2005) Nathalie Girouard and Christophe André

433. Product Market Competition and Economic Performance in the United Kingdom (June 2005) Maria Maher and Michael Wise

432. The Benefits of Liberalising Product Markets and Reducing Barriers to International Trade and Investment: the Case of the United States and the European Union (June 2005)

431. Boosting Growth through Greater Competition in Denmark (May 2005) Martin Jørgensen 